\title{
Following food clouds: feeding association between a minute loricariid and a characidiin species in an Atlantic Forest stream, Southeastern Brazil
}

\author{
Rafael P. Leitão*, Érica P. Caramaschi* and Jansen Zuanon**
}

Following behavior is a widespread feeding tactic among marine fishes, but remains poorly documented for freshwater fishes. The present study describes such association between two freshwater species: the minute armored catfish Parotocinclus maculicauda and the South American darter Characidium sp. During underwater observations in an Atlantic Forest stream, we recorded Characidium sp. closely following P. maculicauda $(<5 \mathrm{~cm})$, catching the particles dislodged by this catfish's grazing activity. The following behavior displayed by the darter is considered opportunistic and possibly favors the capture of preys associated to the periphyton. This study is one of the few records of nuclear-follower feeding association between freshwater fishes and the first one in Atlantic Forest streams.

O comportamento seguidor é uma tática de forrageio bastante conhecida entre peixes marinhos, mas pouco documentada para peixes de água doce. O presente estudo descreve essa associação alimentar entre duas espécies de riacho: o cascudinho Parotocinclus maculicauda e o peixe-canivete Characidium sp. Por meio de sessões de observação subaquática, Characidium sp. foi registrado seguindo $P$. maculicauda $(<5 \mathrm{~cm})$, abocanhando partículas deslocadas pela atividade de pastejo do cascudinho. Esse tipo de comportamento do peixe seguidor é considerado oportunista e possivelmente favorece a captura de presas associadas ao perifíton. Trata-se de um dos poucos registros de associação alimentar do tipo nuclear-seguidor entre peixes de água doce e o primeiro para riachos de Mata Atlântica.

Key words: Following behavior, foraging habits, freshwater, Hypoptopomatinae, Crenuchidae.

\section{Introduction}

Feeding associations may comprise a large number and a diverse array of organisms and foraging tactics, including the so-called nuclear-follower association. This interspecific interaction is characterized by the presence of a nuclear species that promote some kind of disturbance on the bottom while foraging, and a follower species that feeds on items exposed or flushed out by the former (Fricke, 1975; Sazima, 1986; Strand, 1988).

Records of following behavior are recurrent in marine ecosystems, mainly among coral reef fishes (e.g. Strand, 1988; Baird, 1993; Silvano, 2001; Sazima \& Grossman, 2005; Sazima et al., 2005; 2006a, 2006b). In the Gulf of California, almost half of the resident reef fishes was recorded as follower species (Strand, 1988). Sazima et al. (2006b) report that approximately $20 \%$ of the reef fish fauna of Fernando de Noronha Archipelago (tropical West Atlantic) engage in a nuclear-follower association and that nearly $50 \%$ of the fish species that forage by disturbing the bottom act as nuclear species. Besides fishes, other marine organisms like octopuses, sea stars and even turtles were recorded to behave as nuclear species in this kind of feeding association (e.g. Diamant \& Shpigel, 1985; Gibran, 2002; Sazima et al., 2004).

Among freshwater fishes, however, nuclear-follower association records are scarce, but interactions between two species of cypriniforms from North American streams (Baker $\&$ Foster, 1994) and cichlids from an African lake (Stauffer $e t$ al., 1996) qualify as following associations. In the Neotropics, Sazima (1986) recorded Astyanax bimaculatus (Characidae) as a follower species that feeds on insects, crustaceans, plant debris and algae flushed out by the foraging activity of Corydoras polystictus (Callichthyidae) in a freshwater pond in the Brazilian Pantanal. Sabino \& Sazima (1999) reported a remarkable case of monkeys (Cebus apella) followed by schools of the characid fish Brycon microlepis (= hilarii),

\footnotetext{
*Laboratório de Ecologia de Peixes, Departamento de Ecologia, Universidade Federal do Rio de Janeiro, Av. Brigadeiro Trompowski, s/nº, Ilha do Fundão, 21941-541 Rio de Janeiro, RJ, Brazil. ecorafa@gmail.com; erica@pq.cnpq.br

**Coordenação de Pesquisas em Biologia Aquática, Instituto Nacional de Pesquisas da Amazônia - INPA, 69083-970 Manaus, AM, Brazil. zuanon@inpa.gov.br
} 
that readily took the fruits dropped in the water by the monkey's destructive foraging in the riparian forest at Bonito region, Paraguay River drainage.

We describe herein a case of feeding association between two freshwater fishes in an Atlantic Forest stream in Southeastern Brazil, involving the minute suckermouth catfish $\mathrm{Pa}$ rotocinclus maculicauda (Siluriformes: Loricariidae) as the nuclear species, and the South American darter Characidium sp. (Characiformes: Crenuchidae) as the follower one.

\section{Material and Methods}

The study was conducted in rio do Ouro (22 $17^{\prime} 15^{\prime \prime} \mathrm{S}, 42$ $\left.{ }^{\circ} 00 ’ 37 " \mathrm{~W}\right)$, a fourth order tributary of rio São Pedro, Macaé river basin, northern Rio de Janeiro state. The sampled stream stretch is bordered by a second-growth Atlantic Forest and is characterized by clear water with rocks, logs and dead leaves banks scattered over a sand bottom substrate. The studied stream reach was $20 \mathrm{~m}$ in length, less than one meter deep and $3-10 \mathrm{~m}$ wide, with water level variations in function of local rainfall and seasonal dynamics.

We performed diurnal direct observations of the association between individuals of Parotocinclus maculicauda and Characidium sp. while snorkeling, using the sequence sampling method ( $c f$. Lehner, 1979). Each monthly session lasted about 40 min and was conducted in February, March, July and September 2005, totaling four sessions and $160 \mathrm{~min}$ of sampling. Following interactions were registered in situ by means of underwater photographs. Voucher specimens of $P$. maculicauda and Characidium sp. were deposited in the Fish Collection of Museu Nacional do Rio de Janeiro (MNRJ 30875, MNRJ 30877, MNRJ 30878, MNRJ 30882). Characidium sp. is a new species and will be described elsewhere (P. A. Buckup and R. P. Leitão, in prep.).

\section{Results}

Nuclear-follower associations between Parotocinclus maculicauda and Characidium sp. were recorded in three of the four observation sessions (February, March and July). The association was registered only when both fish species were positioned on a rocky substrate (large rocks up to $1 \mathrm{~m}$ in diameter) covered by periphyton and a fine sediment layer, in areas of high water flow (current speed up to $50 \mathrm{~cm} / \mathrm{s}$ at the stream bottom). Individuals of the minute catfish $P$. maculicauda were observed grazing singly or in groups on periphytic algae attached to the rocks, making head and body movements over short distances ahead and sideways during foraging [see Buck \& Sazima (1995) for examples of such movements in other Loricariidae]. When foraging the catfish occasionally drifted downstream for a short distance displaced by the water flow, but quickly resumed its position. This activity set frequently suspended the sediment deposited on the rock surface, resulting in small clouds of particles drifting away and quickly dispersing by the fast flowing water.
The feeding association was characterized by the presence of a single individual of Characidium sp. standing downstream of, and in close proximity (ca. $5 \mathrm{~cm}$ ) with the foraging catfish (Fig. 1). At this position, the darter adopted a sit-andwait foraging tactic (sensu Sazima, 1986) and fed on particles suspended by the grazing activity of the catfish (Fig. 2). The nuclear-follower interaction lasted between a few seconds to about five minutes and each of these events occasionally occurred more than once during the 40 min observation session.

Although we observed a ratio of one individual of Characidium sp. to about 15 P. maculicauda, feeding association events comprised almost always only one individual of each species. However, we observed a single case of one individual of the darter alternately following two closely positioned catfishes.

\section{Discussion}

Parotocinclus maculicauda is a small sized catfish that apparently doesn't produce a high substrate disturbance during its foraging. Nevertheless, this species clearly played the nuclear role in the feeding association herein observed. Although this role isn't strictly performed by bottom disturbing organisms, substrate disturbance is considered a strong predictor of the nuclear role in a nuclear-follower association (Sazima et al., 2006b). In the studied stream, a characteristic bottom-dwelling species that stirs up a dense sediment cloud is the bearded cory Scleromystax barbatus, Callichthyidae (RPL, pers. obs.); however, no feeding associations involving this species was yet observed in rio do Ouro. Sazima (1986) registered another callichthyid species, Corydoras polystictus, being followed by Astyanax bimaculatus during its foraging activity in a Pantanal pond. It is possible that differences in microhabitat preferences by Characidium sp. and Scleromystax barbatus in rio do Ouro may impair the occurrence of a feeding association between these two species.

Dislodging sediment, algae and (possibly) small animals during foraging activities of loricariid catfishes was already observed by Buck \& Sazima (1995) in an Atlantic Forest stream, but without any records of following associations such as the observed in the present study. Species of the genus Characidium are known to feed predominantly on substrate-dwelling aquatic insect larvae (Godoy, 1975; Costa, 1987; Sabino \& Castro, 1990; Castro \& Casatti, 1997; Uieda et al., 1997; Aranha et al., 2000; M. P. Albrecht, pers. comm.). Chironomidae (Diptera) larvae were the most abundant item on the diet of Characidium fasciatum and C. gomesi in MogiGuaçu river basin (Godoy, 1975). Besides Chironomidae, Ephemeroptera nymphs and Simuliidae larvae were the most important items on the diet of C. lanei and C. pterostictum in Cabral stream, Paraná State, Southern Brazil (Aranha et al., 2000). Considering the benthic habits and the small size of those insect preys, we believe that the foraging activities of P. maculicauda on the fine sediment-periphyton layer over 


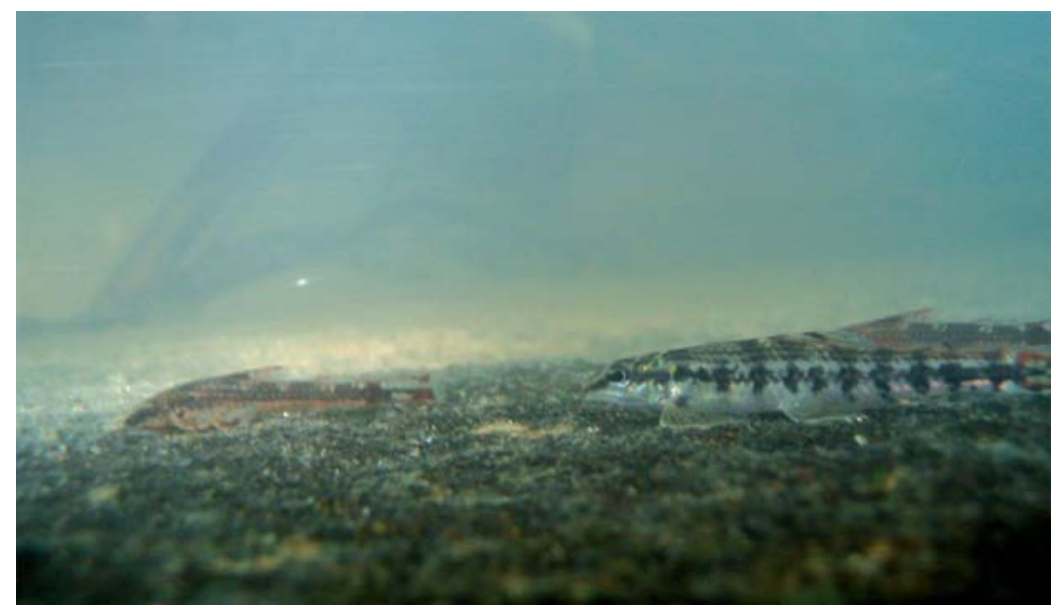

Fig. 1. An individual of Characidium sp. positioned behind a grazing catfish, Parotocinclus maculicauda, on a large submerged rock in a fast flowing stretch of the rio do Ouro stream. Photo by R. Leitão.

the rocks could dislodge these items and make them available for Characidium sp.

Behavioral studies on Characidium species (e.g. Sazima, 1986; Sabino \& Castro, 1990; Aranha et al., 1998; Sabino \& Silva, 2004, Zuanon et al., 2006) revealed the use of two main foraging tactics: "sit-and-wait predation" (sensu Sazima, 1986), in which the fish stays stationary on the bottom and preys on small invertebrates spotted in the bottom or drifted by the current; and "hunting by speculation" (sensu Curio, 1976), in which the fish actively search for preys buried in the upper layer of the substrate. In this sense, we suggest that the following behavior displayed by Characidium sp. represents a modified sit-and-wait foraging tactic, capitalizing upon a food supply (previously attached to the substrate) provided by the catfish's feeding activity. The second foraging tactic was not registered to Characidum sp. in our observations in rio do Ouro.

Individuals of $P$. maculicauda were observed predominantly in the middle portion of the stream channel, occupying spots with high water flow and hard substrates like rocks, logs, and twigs (RPL, pers. obs.). Besides Characidium sp., other Characidium species are known to occupy sites with swift water current (Costa, 1987; Sabino \& Castro, 1990; Aranha et al., 1998), over gravel and rock bottom (our pers. obs.). A high amount of preys per unit of time may be available under swift water flow (Fausch, 1984); however, the ability of some fishes to locate and catch them is lessened under this condition (Hill \& Grossman, 1993), which may be possible in the case of Characidium sp. Thus, the feeding association of Characidium sp. with P. maculicauda would enhance its foraging success.

The feeding association reported herein possibly occurs because the two species occupy similar microhabitats, and forage during the same daytime period. Characidium species are diurnal foragers, as most of the Characiformes (LoweMcConnell, 1987; Sabino \& Castro, 1990). On the other hand, the vast majority of catfishes (Siluriformes) are typically nocturnal (Lowe-McConnell, 1987). However, the diurnal habits of the "cascudinhos" of the subfamily Hypoptopomatinae represent one of the exceptions among the catfishes in general and among the Loricariidae in particular (Buck \& Sazima, 1995; Schaefer, 2003). In fact, P. maculicauda was found more active and in higher abundances during the daylight period, when compared with nocturnal observations in rio do Ouro (RPL, pers. obs.). Finally, we believe that the scarcity of records of this kind of behavioral interaction among freshwater fishes mainly reflects the lack of natural history studies in such environments, rather than its rarity.

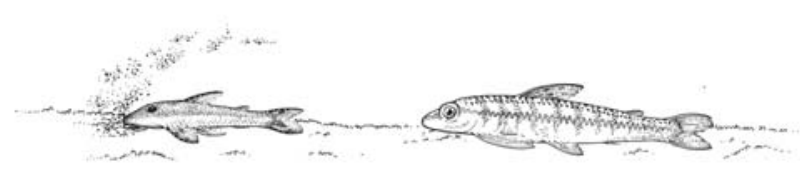

a

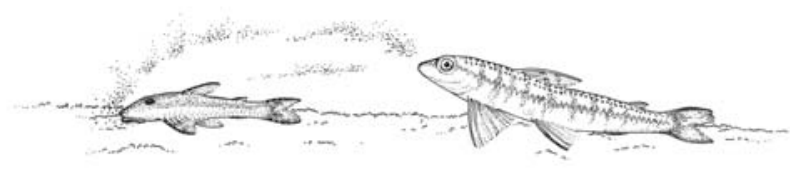

b

Fig. 2. The grazing activity of Parotocinclus maculicauda that dislodges particles, resulting in small clouds (a); and Characidium sp. standing downstream of the foraging catfish, adopting a sit-and-wait foraging tactic to feed on the particles (b). Illustration by A. Peixoto. 


\section{Acknowledgements}

We thank Paulo A. Buckup and Roberto E. dos Reis for the determination and confirmation of the species and IBAMA for collect permit $(004 / 2004)$. We are also grateful to the Laboratório de Ecologia de Peixes/ UFRJ fieldwork staff, Marcelo F. G. de Brito, Victor T. Cardoso, Miriam P. Albrecht and Daniele Kasper for comments and suggestions; and to José Sabino and Cristina Sazima for suggestions of literature references. EPC thanks for the CNPq (proc. $n^{\circ} .309506 / 2003$ 4). Finally, we are grateful to the anonymous referees for the critical revision and valuable suggestions. This study is part of the MSc. dissertation (PPGE-UFRJ) of RPL and was financially supported by CNPq (proc. $n^{\circ}$. 1327822004-9).

\section{Literature Cited}

Aranha, J. M. R., J. H. C. Gomes \& F. N. O. Fogaça. 2000. Feeding of two sympatric species of Characidium, C. lanei and $C$. pterostictum (Characidiinae) in a coastal stream of Atlantic Forest (Southern Brazil). Brazilian Archives of Biology and Technology, 43(5): 527-531.

Aranha, J. M. R., D. F. Takeuti \& T. M. Yoshimura. 1998. Habitat use and food partitioning of the fishes in a coastal stream of Atlantic Forest, Brazil. Revista de Biología Tropical, 46: 955963.

Baird, T. A. 1993. A new heterospecific foraging association between the puddingwife wrasse, Halichoeres radiatus, and the bar jack, Caranx ruber: evaluation of the foraging consequences. Environmental Biology of Fishes, 38: 393-397.

Baker, J. A. \& S. A. Foster. 1994. Observations on a foraging association between two freshwater stream fishes. Ecology of Freshwater Fish, 3(3): 137-139.

Buck, S. \& I. Sazima. 1995. An assemblage of mailed catfishes (Loricariidae) in southeastern Brazil: distribution, activity, and feeding. Ichthyological Exploration of Freshwaters, 6(4): 325 332.

Castro, R. M. C. \& L. Casatti. 1997. The fish fauna from a small forest stream of the upper Paraná River basin, Southeastern Brasil. Ichthyological Exploration of Freshwaters, 7(4): 337-352.

Costa, W. J. E. M. 1987. Feeding habits of a fish community in a tropical coastal stream, Rio Mato Grosso, Brazil. Studies on Neotropical Fauna \& Environment, 22(3): 145-153.

Curio, E. 1976. The Ethology of Predation. Berlin, Springer-Verlag, 249 p.

Diamant, A. \& M. Shpigel. 1985. Interspecific feeding association of groupers (Teleostei: Serranidae) with octopuses and moray eels in the Gulf of Eilat (Aqaba). Environmental Biology of Fishes, 13: 153-159.

Fausch, K. D. 1984. Profitable stream positions for salmonids: relating specific growth rate to net energy gain. Canadian Journal of Zoology, 62: 441- 451.

Fricke, H. W. 1975. The role of behaviour in marine symbiotic animals. Pp. 581-594. In: Jennings, D. H. \& D. L. Lee (Eds.). Symbiosis, Symposia of the Society for Experimental Biology, 29. Cambridge University Press, Cambridge, 633p.

Gibran, F. Z. 2002. The sea basses Diplectrum formosum and D. radiale (Serranidae) as followers of the sea star Luidia senegalensis (Asteroidea) in southeastern Brazil. Brazilian Journal of Biology, 62(4A): 591-594.
Godoy, M. P. 1975. Peixes do Brasil: Subordem Characoidei. Piracicaba, SP, Ed. Franciscana, 847p.

Hill, J. \& G. Grossman. 1993. An energetic model of microhabitat use for rainbow trout and rosyside dace. Ecology, 74(3): 685-698.

Lehner, P. N. 1979. Handbook of Ethological Methods. New York, Garland STPM Press, 403p.

Lowe-McConnell, R. H. 1987. Ecological Studies in Tropical Fish Communities. Cambridge University Press, 382p.

Sabino, J. \& R. M. C. Castro. 1990. Alimentação, período de atividade e distribuição espacial dos peixes de um riacho da floresta Atlântica (Sudeste do Brasil). Revista Brasileira de Biologia, 50(1): 23-36.

Sabino, J. \& I. Sazima. 1999. Association between fruit-eating fish and foraging monkeys in western Brazil. Ichthyological Exploration of Freshwaters, 10(4): 309-312.

Sabino, J. \& C. P. D. Silva. 2004. História Natural de Peixes da Estação Ecológica Juréia-Itatins. Pp. 230-242. In: Marques, O. A. V. \& W. Duleba. (Eds.). Estação Ecológica Juréia-Itatins: Ambiente físico, flora e fauna. Ribeirão Preto, Ed. Holos, 384p.

Sazima, I. 1986. Similarities in feeding behaviour between some marine and freshwater fishes in two tropical communities. Journal of Fish Biology, 29: 53-65.

Sazima, C., R. M. Bonaldo, J. P. Krajewski \& I. Sazima. 2005. The Noronha wrasse: a jack-of-all-trades follower. Aqua, Journal of Ichthyology and Aquatic Biology, 9: 97-108.

Sazima, C. \& A. Grossman. 2005. A non-digging zoobenthivorous fish attracts two opportunistic predatory fish associates. Neotropical Ichthyology, 3(3): 445-448.

Sazima, C., A. Grossman, C. Bellini \& I. Sazima. 2004. The moving gardens: reef fishes grazing, cleaning, and following green turtles in SW Atlantic. Cybium, 28(1): 47-53.

Sazima, C., J. P. Krajewski, R. M. Bonaldo \& P. R. Guimarães. 2006a. The goatfish Pseudupeneus maculatus and its follower fishes at an oceanic island in the tropical west Atlantic. Journal of Fish Biology, 69: 1-9.

Sazima, C., J. P. Krajewski, R. M. Bonaldo \& I. Sazima. 2006b. Nuclear-follower foraging association of reef fishes and other animals at an oceanic archipelago. Environmental Biology of Fishes, 78: 1-11.

Schaefer, S. A. 2003. Subfamily Hypoptopomatinae. Pp. 321-329. In: Reis, R. E., S. O. Kullander \& C. Ferraris Jr. (Eds.) Checklist of the Freshwater Fishes of South and Central America. Porto Alegre, Edipucrs, 729p.

Silvano, R. A. M. 2001. Feeding habits and interspecific feeding associations of Caranx latus (Carangidae) in a subtropical reef. Environmental Biology of Fishes, 60: 465-470.

Stauffer, J. R., T. J. LoVullo \& H. Y. Han. 1996. Commensalistic feeding relationships of three Lake Malawi fish species. Transactions of the American Fisheries Society, 125(2): 224-229.

Strand, S. 1988. Following behavior: interspecific foraging associations among Gulf of California reef fishes. Copeia, 2: 351-357.

Uieda, V. S., P. Buzzato \& R. M. Kikuchi. 1997. Partilha de recursos alimentares em peixes em um riacho de serra do sudeste do Brasil. Anais da Academia Brasileira de Ciências, 69: 243-252.

Zuanon, J., F. A. Bockmann \& I. Sazima. 2006. A remarkable sanddwelling fish assemblage from central Amazonia, with comments on the evolution of psammophily in South American freshwater fishes. Neotropical Ichthyology, 4(1): 107-118.

Submitted April 2007 Accepted May 2007 